\title{
PLURIACTIVITY OF FARMING FAMILIES IN POLAND STATUS AND CHANGES IN 2013-2016
}

\author{
MARTA BEACD
}

\begin{abstract}
The purpose of the article is to present the state and changes in the pluriactivity of farming families in Poland in the years 2013-2016. The analysis was based on data from the representative farm structure survey (FSS) to which every EU country is required. Its results are as follows: 1) in 2016, only 1.3\% of people were pluriactive, while in 2013 this percentage amounted to $31.5 \%$; 2) the diversification of activities other than agriculture, but directly related to an agricultural holding is still carried out by a relatively small percentage of holdings: in 2016 it amounted to 2.9\%; 3) over half of households with a farm user obtained income from wage labour (the most popular form of work outside a farm, as in the years 2005-2010) in addition to income from agricultural activity. The most surprising change was an increase of more than half a million persons engaged only in agriculture and a decrease of more than a million of pluriactive persons, and thus an interruption of the multiannual ratio of pluriactive persons in relation to persons engaged only in agriculture, which was 1:3. Possible reasons for this may be the following aspects: a decrease in the number of farms, including farms up to 1 ha, with the largest number of pluriactive persons, return to specialisation, phenomenon of repeasantisation, possible impact of the 500+ programme on abandoning non-agricultural works and finally the possibility of a statistical error in 2016 studies (another study, BAEL, does not show a decrease in the importance of pluriactivity). The matter is important, because the FSS is a source of official national data for EU statistics.
\end{abstract}

Keywords: Poland, farming families, diversification, pluriactivity.

JEL codes: E24, J43, 013, R20.

Marta Błąd, PhD, DSc, Institute of Rural and Agricultural Development, Department of European Integration; ul. Nowy Świat 72, 00-330 Warsaw, Poland (marta.blad@wp.pl).

ORCID iD: 0000-0003-3882-6281. 


\section{Introduction}

Following Poland's accession to the European Union, our country was obliged to conduct representative farm structure surveys $(\mathrm{FSS})^{1}$ conducted in each EU country. Since the accession, four such surveys have been conducted in 2005, 2007, 2013 and 2016. In 2010, it was conducted as part of the general agricultural census.

These surveys provide a lot of data, including the information on pluriactivity in farming families in Poland which is of interest to the author. This phenomenon is a fascinating study subject as it is common and universal in agriculture, takes place in countries with different levels of development (cf. Błąd, 2011). On average, every third farmer across the Union is pluriactive (cf. Other gainful..., 2008, p. 1; Thomson, 2019, p. 296 - 2010 data).

In foreign literature, the terms used are "pluriactivity" and related "diversification" (inter alia, Evans and Ilbery, 1993; Kinsella, Wilson, de Jong and Renting, 2000; Durand and Huylenbroeck, 2004; Bessant, 2006). For the purposes of this study, we assume, after Durand and Huylenbroeck (2004, p. 12), that "pluriactivity" refers to both agricultural and non-agricultural activities conducted by farmers or members of an agricultural household. In the first case, we are talking about "pluriactivity of a farmer" and, in the second - "pluriactivity of a farming family". On the other hand, diversification is attributed to differentiating activities within the place of performing agricultural work, through the use of land resources or farm equipment ${ }^{2}$. This term is defined similarly in the Farm Structure Survey in the EU, and namely "pluriactivity" refers to a person, i.e. a farmer (pluriactivity of a farmer) and "diversification" to a farm (diversification of a holding) (Other gainful..., 2008, p. 5).

The objective of the article is to define the scale and changes in the employment of pluriactive persons, diversification of activities on farms and the income situation of pluriactive families, in the years 2013-2016, based on the FSS data. Descriptive and comparative analysis methods were used. The paper is a continuation of studies conducted in the previous years ${ }^{3}$ and presented in the article Pluriactivity in farming families in Poland. The state and trends of change in the years 2005-2010 (Błąd, 2013). The following article contains a research postulate that pluriactivity of both farmers and farming families, just like in previous years, is still gaining importance.

\footnotetext{
${ }^{1}$ The survey covered all farms of legal persons and non-corporate organisational units and a selected sample of individual farms (around 200,000).

${ }^{2}$ Diversification concerns taking up a gainful activity which is not strictly an agricultural production activity, but is carried out based on farm resources or products produced on the farm (e.g. agritourism, crafts, renewable energy production, processing or the provision of health, social and educational services).

${ }^{3}$ In connection with introduction of gradual changes in the methodology of agricultural studies from 2010 with a view to adapting to EU standards and taking into account transformations in Polish agriculture, as well as to using administration sources in a broader manner, the definition of a farm has changed. According to the currently applicable definition, the farm structure surveys in 2013 and 2016 did not include owners of agricultural land not involved in agricultural activities nor owners of agricultural land of less than 1 ha involved in small-scale agricultural activities. Therefore, the 2013 and 2016 data on farms in total and on farms of up to 1 ha of UAA are comparable only to each other and are not comparable to similar data from 2002-2010. The only data for farms involved in agricultural activities with an area of more than 1 ha of UAA can be compared in this way (GUS, 2017, p. 17).
} 


\section{Changes in the number of persons working on farms ${ }^{4}$ and in the number of pluriactive persons ${ }^{5}$}

According to the FSS data, the number of family members working on individual farms decreased. The decrease in the years covered by the study amounted to 481.3 thousand persons, i.e. $16.5 \%$ (Table 1). This fact is in line with a trend noted in previous years (cf. Błąd, 2013). This results from the decreased number of farms in total: in the years 2013-2016 by 18.3 thousand (by 1.3\%), including the decreased number of individual farms of more than 1 ha by 7.2 thousand (by $0.6 \%$ ) (GUS, 2017, p. 61) ${ }^{6}$. This is expressed in reduced labour inputs for agricultural activities by 254.2 thousand AWU (13.7\%) (cf. GUS, 2014, p. 286; 2017, p. 244).

In 2016, there was a rather surprising change: unlike in previous years, the number of persons working exclusively in agriculture increased by more than half a million (by 23.5\%), while the number of persons combining agricultural and non-agricultural work decreased by more than 1 thousand (representing a decrease by as much as $96.5 \%$ ) (cf. Table 1 ). As a result of this rather rapid change, the structure of persons - family members working on individual farms - changed. While in 2013 persons working only on farms accounted for, on average, $68.6 \%$, in 2016 this percentage was $98.7 \%$ (Table 1 ). In 2016, only $1.3 \%$ of persons combined agricultural and non-agricultural work. This is a very clear decrease when compared to the previous study year, when $31.3 \%$ of persons were pluriactive. Thus, while in 2013 it could be said that every third person was pluriactive, in 2016 it was every eighth person. It is worth noting that the largest group among pluriactive persons were those for whom non-agricultural work was the main work, so agricultural activities were additional for them.

\footnotetext{
${ }^{4}$ The Central Statistical Office (GUS) statistics do not use the term "farmer", but other close concepts: "farming population", "farm workers", "farm users". For the purposes of this study, I regard, sensu largo, farmers as "farm workers". Here, I omit the sociological differentiation of this conceptual category described by Maria Halamska (2016, pp. 36-37).

${ }^{5}$ The term pluriactivity, a phenomenon of combining agricultural work with non-agricultural work, refers to the following categories of persons used by GUS: "working mainly on their farm and additionally outside the farm" and "working mainly outside their farm and additionally on their own farm". Main work is the one performed for more working hours, and if both (or more) of them took the same amount of time, main work is the one that brings higher income. Maria Halamska (2016, p. 63) calls the two above-mentioned categories of communities "quasi-farmers" as their employment status is not clear.

${ }^{6}$ When compared to the PSR 2010 results, converted in line with the new definition of the farm, in 2013 the number of farms in total decreased by around 80,000 , i.e. by $5.3 \%$ (GUS, 2014, p. 75).
} 
Table 1

Working family members on individual farms with an area of more than 1 ha of UAA

\begin{tabular}{|c|c|c|c|c|c|c|c|c|c|c|}
\hline \multirow{4}{*}{ Years } & \multirow[b]{3}{*}{ Tota } & & \multirow{3}{*}{\multicolumn{2}{|c|}{$\begin{array}{l}\text { Working } \\
\text { on the farm } \\
\text { only }\end{array}$}} & \multicolumn{6}{|c|}{ Pluriactive } \\
\hline & & & & & \multirow{2}{*}{\multicolumn{2}{|c|}{ Total $^{\mathrm{a}}$}} & \multicolumn{4}{|c|}{ Including: } \\
\hline & & & & & & & \multicolumn{2}{|c|}{$\begin{array}{l}\text { Working mainly } \\
\text { on the farm } \\
\text { and additionally } \\
\text { outside the farm }\end{array}$} & \multicolumn{2}{|c|}{$\begin{array}{l}\text { Working mainly } \\
\text { outside the farm } \\
\text { and additionally } \\
\text { on the farm }\end{array}$} \\
\hline & thous. & $\%$ & thous. & $\%$ & thous. & $\%$ & thous. & $\begin{array}{c}\% \text { among } \\
\text { pluriactive } \\
\text { persons }\end{array}$ & thous. & $\begin{array}{c}\% \text { among } \\
\text { pluriactive } \\
\text { persons }\end{array}$ \\
\hline 2013 & $3,404.7$ & 100 & $2,337.1$ & 68.6 & $1,067.6$ & 31.3 & 111.8 & 10.5 & 955.8 & 89.5 \\
\hline 2016 & $2,923.4$ & 100 & $2,885.8$ & 98.7 & 37.6 & 1.3 & 8.8 & 23.4 & 28.8 & 76.6 \\
\hline
\end{tabular}

a includes the total of categories: "working mainly on the farm and additionally outside the farm" and "working mainly outside the farm and additionally on the farm"

Source: own calculations based on data in: GUS, 2014, p. 286; GUS, 2017, p. 244.

In both 2013 and 2016, men combined work on the farm with other work relatively more often than women, and from the point of view of family relationships in 2013, this was practised more often by users' spouses than by users themselves and other family members, while in 2016 more often by users than users' spouses and other family members. (GUS, 2014, p. 164; 2017, p. 136).

The percentage of pluriactive persons on farms was decreasing along with the growing area of farms. The larger was the farm, the lower was the number of those persons and higher was the number of family members working exclusively on the farm. For example, in 2013, on farms with an area of up to 1 ha $7,64.0 \%$ of persons worked exclusively on the farm, $3.1 \%$ worked mainly on the farm and also outside the farm, while $32.9 \%$ worked mainly outside the farm and also on the farm. This means that $36.0 \%$ of those working on farms in this area were pluriactive. For farms with an area of 5-10 ha of UAA, this percentage was $30.9 \%$ and for farms of 30-50 ha it accounted for 13.1\% (GUS, 2014, p. 165).

Pluriactivity is therefore more common on relatively smaller farms than on large ones, although in the case of large farms it is also of some importance in terms of income. This is confirmed by the results of the Polish FADN sample. In 2016, the average share of off-farm income in total farmer's family income was $20 \%$ (Juchniewicz, Kambo and Michalak, 2018, p. 23 and 25). Therefore, it can be concluded that, for relatively small farms, pluriactivity is rather a way to survive, and for large ones it stabilises and improves income security and is a strategy to better manage and use farm resources.

\footnotetext{
${ }^{7}$ According to the current definition of the farm, included in FSS 2013 and FSS 2016, farms of natural (individual) persons are only those below 1 ha which pursue agricultural activities while meeting the determined thresholds, e.g. 0.5 ha for fruit tree plantations, 0.3 ha for horticultural and ornamental nurseries, 5 cows, 50 pigs in total (cf. GUS, 2014, p. 18 and GUS, 2017, p. 18).
} 


\section{Scale of diversification of activities on farms}

The GUS distinguishes, although not explicitly, two types of farms pursuing both agricultural and non-agricultural activities. The first group here is called Group A and includes farms pursuing non-agricultural activities directly related to the farm, using farm resources (labour, site, buildings, machinery park, etc.) or products produced on the farm. In the GUS nomenclature, they are referred to as "farms pursuing gainful non-agricultural activities directly related to the farm". I call this activity diversification, according to my definition.

The second group, referred to here as Group B, includes farms where family members pursue non-agricultural activities not related to their own farm. This group comprises farms pursuing non-agricultural activities, where "labour only" is used from farm resources. According to the definition adopted in this article, such activities are referred to as pluriactivity, both for pursuing own non-agricultural activities and to wage labour, however, to a much rarer case of working on the farm on someone's account.

Data on Group A is published by GUS by type of pursued non-agricultural activities (cf. Table 3), while data on Group B does not appear separately and is published together with data on Group A in the part of the FSS results dedicated to income. Together, Group A and Group B (without "wage labour" which is a separate category) are referred there jointly as "farms with income from non-agricultural activities".

This part of the study concerns Group A farms. The state and change in the number of those farms in the years 2013-2015, against a background of the total number of farms, is as follows. The share of group of farms diversifying their activities relatively small. In 2013, they accounted for only $2.6 \%$ of both total farms and individual farms, and in $2016-2.9 \%$; in the study years, the group of diversified farms increased by 4 thousand (by 10.6\%) (Table 2). The percentage of farms pursuing non-agricultural activities was increasing along with the increase in the area of UAA (therefore, this is an inverse relation than for pluriactivity): on farms of up to $1 \mathrm{ha}$, it was almost 4\%, in the group of farms with an area of 100 ha or more about $10 \%$. The average area of diversifying farms was nearly twice as high as the average for all (individual) farms and amounted to 19.06 ha of UAA (GUS, 2017, p. 63). To some extent this is understandable, if diversification is based on farm resources, they, in particular, land and capital resources, must be of size suitable for the specificities of non-agricultural work. 
Diversification of activities on farms

Table 2

\begin{tabular}{|c|c|c|}
\hline Specification & 2013 & 2016 \\
\hline Number of farms in total (thousand) & $1,429.1$ & $1,410.7$ \\
\hline Number of individual farms of more than 1 ha (thousand) & $1,391.1$ & $1,383.9$ \\
\hline $\begin{array}{l}\text { Number of farms pursuing non-agricultural activities directly related } \\
\text { to the farm (thousand) }\end{array}$ & 36.8 & 40.8 \\
\hline $\begin{array}{l}\text { Percentage of number of farms pursuing non-agricultural activities } \\
\text { directly related to the farm (thousand) in the total number of farms }\end{array}$ & $2.6 \%$ & $2.9 \%$ \\
\hline $\begin{array}{l}\text { Number of individual farms pursuing non-agricultural activities directly } \\
\text { related to the farm (thousand) }\end{array}$ & 36.3 & 40.3 \\
\hline $\begin{array}{l}\text { Percentage of number of individual farms pursuing non-agricultural } \\
\text { activities directly related to the farm (thousand) in the total number } \\
\text { of farms }\end{array}$ & $2.6 \%$ & $2.9 \%$ \\
\hline
\end{tabular}

Source: GUS, 2014, p. 187 and 192, GUS, 2017, p. 61, 157 and 162.

Table 3

Individual farms diversifying their activities by types of activity

\begin{tabular}{lrrrr}
\hline & \multicolumn{2}{c}{2013} & \multicolumn{2}{c}{2016} \\
\cline { 2 - 5 } & Number & Percentage & Number & Percentage \\
\hline Total & 36,342 & 100 & 40,312 & 100 \\
including: & & & & \\
agritourism & 8,226 & $22.6 \%$ & 10,610 & $26.3 \%$ \\
crafts & 2,360 & $6.5 \%$ & 1,392 & $3.5 \%$ \\
processing of agricultural products & 2,411 & $6.6 \%$ & 2,667 & $6.6 \%$ \\
renewable energy production & 228 & $0.6 \%$ & 354 & $0.9 \%$ \\
on-farm processing of raw wood & 1,767 & $4.9 \%$ & 1,137 & $2.8 \%$ \\
aquaculture & 1,418 & $3.9 \%$ & 921 & $2.3 \%$ \\
agricultural contract work & 4,349 & $12.0 \%$ & 3,795 & $9.4 \%$ \\
non-agricultural contract work & 1,805 & $5.0 \%$ & 1,453 & $3.6 \%$ \\
processing & 1,085 & $3.0 \%$ & & \\
forestry & & & & \\
provision of health, social, educational services &. & & 1,156 &. \\
other activities & 16,654 & $45.8 \%$ & 17,922 & $44.5 \%$ \\
\hline
\end{tabular}

Source: GUS, 2014, p. 295; GUS, 2017, p. 310. 
The study on the farm structure collects information on diversified farms by type of activities (Table 3). These categories are the same in both study years, exclusive of two: forestry and provision of health, social and educational services, identified for 2016. The most popular activity was agritourism accounting for more than $20 \%$ of all activities in both years; in 2016, this activity was pursued by 2,384 farms more than in 2013 (an increase by 5.9\%) (cf. Table 3). There is also an increase in interest in renewable energy production: the number of farms increased by more than half (although they represent only less than 1\% of all diversified farms).

Farms with the largest area (average area of UAA - 97.9 ha) produced renewable energy, the smallest farms (6.4 ha) were involved in crafts (GUS, 2017, p. 63).

\section{Importance of non-agricultural income in total agricultural income of farms}

The income analysis refers to the GUS category "household with a farm user". This means a group of persons living and earning their livelihoods together if among them there is a person managing an individual farm. According to the FSS data, in 2013 1,425.4 thousand households with an individual farm user received income from their agricultural activities (GUS, 2014, p. 138) while in 2016 this number was lower by $1.6 \%$ (GUS, 2017, p. 113).

Among households with a farm user, there were pluriactive farms (families) that also gained income outside the farm. Most of them, nearly half (in 2016-47.7\%), in addition to agricultural income, gained income from wage labour (a decrease by $2.1 \mathrm{pp}$ when compared to 2013). Among sources of earnings, it was the more popular form of off-farm work, just like in previous years (Błąd, 2013), followed by non-agricultural activities (15.2\%) (Table 4). "Non-agricultural activity" means an activity pursued on own account, both based on farm resources (Group A farms) and not related to the farm (Group B farms without wage labour). Wage labour undertaken by members of households with a farm user is usually non-agricultural, yet work on another farm is not ruled out if it is performed on someone's account. The analysis of household income structure, in particular the fact that around half of these households feed their budget with wage labour, indicates the huge importance of taking up non-agricultural work in the life of farming families (although, as it has been shown, the number of pluriactive persons decreased radically, which may mean a trend to specialisation). We should stress an increase in the number of households gaining other unearned income (an increase by $68.2 \%-\mathrm{cf}$. Table 4 ) which can be linked to the effect of payments related to the 500+ programme. 
Table 4

Income of households with a farm user

\begin{tabular}{lcccc}
\hline \multirow{2}{*}{\multicolumn{1}{c}{ Specification }} & \multicolumn{2}{c}{2013} & \multicolumn{2}{c}{2016} \\
\cline { 2 - 5 } & Number & Percentage & Number & Percentage \\
\hline Households with income due to: & & & & \\
Non-agricultural activities & 216,447 & 15.2 & 214,447 & 15.2 \\
Wage labour & 709,544 & 49.8 & 671,271 & 47.7 \\
Pension and annuity & 440,195 & 30.9 & 464,625 & 33.0 \\
Other unearned income & 63,625 & 4.5 & 106,965 & 7.6 \\
\hline
\end{tabular}

Source: GUS, 2014, p. 434; GUS, 2017, p. 376.

A more accurate picture of importance of pluriactivity in budgets of farming families can be obtained by analysing the structure of households by main source of their income. It turned out that agricultural activities were the main source of livelihood for just over a third of households with an individual farm user. The percentage of households living mainly on agriculture slightly decreased in the years 2013-2016 (from 34.9\% to 34.2\%) (Table 5). An important role was played by wage labour which for just under a third of farms $(31.8 \%$ in 2016; an increase by 1.6 p.p.) was the main source of income. This means that the average modern farming household lives, more or less equally, on agricultural work and on wage labour and is related to agriculture to the same extent as to non-agricultural work. As in previous years (cf. Błąd, 2013), for relatively few farms, non-agricultural work on own account was the main source of income. This distribution of "importance" of share of individual income sources in the budget of farming families was also observed by the author in her own studies (Błąd, 2011), which showed that for more than half of all households covered by the studies, non-farm income was the main income (in one of surveyed areas, this applied to $85 \%$ of families) and that $3 / 4$ of surveyed pluriactive persons preferred wage labour to work on own account. It must also be mentioned that for just over $13 \%$ of households, pensions and annuities (Table 5) were the main source of livelihood.

There was a relation where along with an increase in the area of UAA, there was an increase in the percentage of households where agricultural income exceeded $50 \%$ of all income and the decrease in the percentage of those households where main income was from wage labour (this is a universal relation, which also occurred in previous years - Błąd, 2013). For example, for 2016, the share of farms where main income was agricultural income amounted to $8.3 \%$ - in the group of 1-2 ha of UAA, and $88.7 \%$ among farms with an area of 50-100 ha. On the other hand, the share of farms where main income was an income from wage labour was the largest in the group of 1-2 ha (44.3\%) and the smallest in the group of 100 ha of UAA and more $-1.9 \%$. (GUS, 2017, p. 116). This confirms the rule that pluriactivity is a feature of small rather than large farms, which specialise in agricultural activities. On relatively smaller farms, income from pensions and annuities plays a minor role. 
Table 5

Households with an individual farm user by source of income

\begin{tabular}{lcccc}
\hline \multirow{2}{*}{ Specification } & \multicolumn{2}{c}{2013} & \multicolumn{2}{c}{2016} \\
\cline { 2 - 5 } & Number & Percentage & Number & Percentage \\
\hline $\begin{array}{l}\text { Households where more than } \\
\text { 50\% of income was from: }\end{array}$ & & & & \\
Agricultural activities & 498,171 & 34.9 & 481,018 & 34.2 \\
Non-agricultural activities & 107,611 & 7.5 & 105,606 & 7.5 \\
Wage labour & 430,359 & 30.2 & 446,982 & 31.8 \\
Agricultural activities & 12,800 & 0.9 & 14,749 & 1.0 \\
and wage labour & & & & \\
Wage labour & 42,382 & 2.9 & 45,325 & 3.2 \\
and agricultural activities & 190,179 & 13.3 & 191,269 & 13.6 \\
Pension and annuity & 22,153 & 1.6 & 34,998 & 2.5 \\
Other unearned income & 167. & & & \\
\hline
\end{tabular}

Source: GUS, 2014, p. 197; GUS, 2017, p. 167.

The importance of taking up work outside the farm in farming families, particularly manifested in wage labour, considered through the prism of income, makes us conclude that this phenomenon is a response (reaction) to farmers' income disparity in relation to other socio-economic groups. The GUS representative household budget survey in Poland shows that in the initial period after Poland's accession to the EU there was a constant downward trend in the income disparity of farmers' households in relation to other socio-economic groups. In the years 2008-2009, this trend was halted. The subsequent years meant fluctuations: first, the relations improved in favour of farmers, then income disparities increased. In 2014, the farmers' income situation deteriorated: available income of farmers' households was lower than income of: average household in the country - by $21.6 \%$, workers by $22.1 \%$ (non-physical workers by $39.4 \%$ ), self-employed persons - by $35.6 \%$ and pensioners and disable pensioners - by $24.0 \%$. It was only higher by $1.2 \%$ than income of physical workers (Sytuacja..., 2015, p. 2-3; cf. Kowalski (ed.), 2015, pp. 140-141) ${ }^{8}$. A fairly common way to increase the level of income in farming families is to take up non-agricultural activities; these decisions are largely motivated by economic reasons.

\footnotetext{
${ }^{8}$ It can be mentioned that 2018 was the year when income disparities between households of farmers and other socio-economic groups decreased in favour of farmers. In 2018, available income of farmers' households was lower than income of: average household in the country only by $6.7 \%$, employees - by $7.3 \%$, self-employed persons - by $21.5 \%$, pensioners - by $8.9 \%$. It was only higher than income of households of disabled pensioners - by $16.5 \%$ (cf. Sytuacja..., 2019, pp. 1-2).
} 


\section{Conclusion}

1. Between 2013 and 2016, the number of family members working on farms decreased (a decrease by 16.5\%) (this fact is in line with the trend observed in previous years), which could result from the reduction by $1.3 \%$ in the number of farms, including individual farms of more than 1 ha - by $0.6 \%$, and was expressed in reduced labour inputs on pursuing agricultural activities (AWU) by $13.7 \%$.

2. In 2016, there was a surprising change 9 : the number of persons working exclusively on the farm increased by more than half a million, while the number of pluriactive persons decreased by more than one million. As a result, the structure of members working on family farms was changed. While in 2013, those working only on the farm accounted for $68.5 \%$ (a similar percentage as in the years 2005-2010), there was a strong increase in this percentage in 2016 - up to as much as $98.7 \%$. It is puzzling that half a million persons chose to "be a farmer only", which may mean that those who in the past had combined agricultural and non-agricultural work returned to monoactivity (work on the farm) (but this does not mean that members of farming families do not practise other professions, just the opposite, they could also have a specialisation, but towards nonagricultural work). Perhaps, there were also new farmers who decided it was worth being a farmer (for various reasons, such as profits like: the possibility of receiving direct subsidies or co-financing for farm activities and investments from EU programmes or KRUS insurance) ${ }^{10}$. Here, we can mention the leitmotif of the book authored by a well-known rural sociologist J. van der Ploeg (2009) about repeasantisation taking place in the modern world, namely the return of "peasants", expressed both by the increased number of farmers and their increased autonomy and independence from the global market. Finally, a study question arises: how to include this process in the progressive global (and Polish) process of deagrarisation? The Labour Force Survey (BAEL), conducted quarterly by GUS, shows that the number of those working in agriculture (exclusively or mainly) is decreasing, while the number of those working outside agriculture is increasing. As for the years 2013 and 2016, the number of those working in agriculture in the countryside decreased by $9.6 \%$ and of those working outside agriculture increased by $11.0 \%$ (cf. Frenkel, 2018, p. 56). ${ }^{11}$

3. According to FSS, in 2016 only $1.3 \%$ of persons combined agricultural and non-agricultural work. This is a very clear decrease (by 1,056.1 thousand persons) when compared to the previous study year, when $31.5 \%$ of persons were

\footnotetext{
${ }^{9}$ It should be stressed that FSS 2013 and FSS 2016 used the same methodology, so we cannot talk about a difference resulting from the application of different methodologies, see GUS, 2017, p. 17. The 2013 and 2016 survey forms contain the same questions on pluriactivity (R-SGR. Survey..., 2013, p. 10; 2016, p. 9).

${ }^{10}$ Amanda Krzyworzeka (2014, p. 149) considers "being a farmer" as one of life strategies. While in the past peasants worked the land, as it was basically the only way of work and life available to them, in the modern world opportunities are much greater and being a farmer involves making a choice and making a decision.

${ }^{11}$ Although the BAEL surveys are conducted according to a methodology other than FSS and cannot be compared, observation of trends is allowed.
} 
pluriactive. This is the greatest study surprise, as the percentage of pluriactive persons in relation to those involved in agriculture only (1:3), also recorded in 2005-2010, was interrupted (Błąd, 2013). This decrease may have been contributed to by the increased number of persons working exclusively in agriculture (we can presume that those persons were previously pluriactive and gave up non-agricultural work). In part, this could have been contributed to by the decreased number of farms in total (by 19.7 thousand), including farms of up to 1 ha - by 11.6 thousand (GUS, 2017, p. 61), and these farms are characterised by a relatively large scale of pluriactivity (the percentage of pluriactive persons on farms decreases along with the increasing farm area). It can be assumed that there has been a trend to specialisation - the abandonment of agricultural work to the benefit of non-agricultural work only or taking up only non-agricultural work by members of farming families entering the labour market. Perhaps a kind of hint is the fact that the number of permanently employed wage workers on farms increased rapidly (from 42.1 thousand in 2013 to 84.1 thousand in 2016) (GUS, 2014, p. 286; 2017, p. 244). Probably, it could be determined by returns from European temporary labour migrations. An important role is also played by the demand for work outside agriculture (demand for this work and the degree of absorption of labour resources). The fact that the number and percentage of pluriactive persons decreased deserves further studies focused on the causes of this change (the impact of the 500+ programme on the abandonment of nonagricultural work may need to be taken into account). The results of BSRG to be conducted in 2020 along with the General Agricultural Census will show if this trend is going to be permanent or if this is a temporary (one-off) phenomenon. However, this seems that this is not the twilight of pluriactivity, but a temporary „disturbance" in the long-standing trend of increase in the importance of pluriactiveness (or at least the fact of its maintenance at a similar level). Maybe we should also consider the possibility of a statistical error in the 2016 surveys. This issue is all the more important that the results of FSS are provided to the European Union statistics (Eurostat) as official data from a Member State.

4. The pluriactiveness of farmers or farming families may be related to gainful activities other than agricultural activities but directly related to the farm. This diversification of activities is still carried out in Poland by a relatively small percentage of farms: in 2016 it was $2.9 \%{ }^{12}$, (although there was an increase by 4 thousand farms when compared to 2013). The scale of diversification on farms should be assessed as too small (despite an increase in interest in certain activities, e.g. renewable energy production). This is a great room for action not only on the part of farmers, but also on the part of the state setting the institutional framework for the development of such activities. The strategy for sustainable development of rural areas, agriculture and fisheries 2030, considering the existing solutions to be insufficient, provides for, inter alia, "support for agricultural

${ }^{12}$ On average, across the Union, this percentage is also not satisfactory (6.8\%), but countries such as Denmark $(60.1 \%)$ and Austria (51.7\%) stand out in this regard (Farmers in the EU - statistics 2017, p. 6 and 11). 
and non-agricultural enterprise, support for services conducive to the development of non-agricultural functions of farms (tourism, education, health, care) and the use of potential of agriculture to pursue economic activities accompanying agricultural production" (Strategia..., 2019, p. 85).

5. The importance of taking up non-agricultural work by farming family members can be clearly seen when analysing income of households with a farm user. In 2016, most of them, nearly 50\%, received income from wage labour in addition to agricultural income (a decrease by $2.1 \mathrm{pp}$ when compared to 2013). This attests to the considerable importance of taking up non-agricultural work for the life of farming families (although, as it has been shown, the number of pluriactive persons decreased dramatically, which may mean a trend towards specialisation). Among the sources of profit, wage labour was the most popular form of non-agricultural work, just like in previous years (Błąd, 2013), followed by non-agricultural activities, not being wage labour (15.2\% in both analysed years). Wage labour was the main source of income for around a third of households (especially for the smallest households; along with the increase in the farm area, the percentage of households where major income was from wage labour decreased). As agricultural activities were the main source of livelihood also for about a third of farms, this means that the average modern agricultural household lives on agricultural work to the same extent as on wage labour and is equally related to agriculture in income terms as to non-agricultural work.

6. An analysis of changes in the years 2013-2016 showed that the pluriactivity of a farmer, i.e. a combination of agricultural and non-agricultural work in one person lost its importance, while the pluriactivity of a farming family, i.e. performing various agricultural and non-agricultural work (especially wage labour) within the household by farming family members is a phenomenon that remains important. Thus, a change towards specialisation has been observed: being either a farmer or performing non-agricultural work. I assume that while, in theory, we can consider that the low level of pluriactivity among farmers is to be maintained, we cannot expect that pluriactivity among farming families is to disappear: their budgets are fed quite heavily with non-agricultural income. In this way, the research postulate formulated has been verified only in part: in fact, the importance of pluriactivity of farmers decreased, but the importance of pluriactivity of farming families was maintained. 


\section{References}

Bessant, K.C. (2006). A farm household conception of pluriactivity in Canadian agriculture: motivation, diversification and livelihood. Canadian Review of Sociology and Antropology, Vol. 43, issue 1, p. 51-72.

Błąd, M. (2011). Wielozawodowość w rodzinach rolniczych. Przyczyny, uwarunkowania i tendencje rozwoju. Warszawa: IRWiR PAN.

Błąd, M. (2013). Wielozawodowość w rodzinach rolniczych w Polsce. Stan i tendencje zmian w latach 2005-2010. Zagadnienia Ekonomiki Rolnej, No. 2(335), p. 71-84.

Durand, G., van Huylenbroeck, G. (2003). Multifunctionality and rural development: general Framework. In: G. van Huylenbroeck, G. Durand (ed.), Multifunctional agriculture. A new paradigm for european agriculture and rural development. Hampsire: Asgate Publising Company.

Evans, N., Ilbery, B. (1993), Pluriactivity, part-time farming and the farm diversification debate. Environment and Planning A, Vol. 25, p. 945-959.

Farmers in the EU - statistics (2017). Retrieved from: https://ec.europa.eu/eurostat/statistics-explained/pdfscache/62101.pdf (access date: 29.08.2019).

Frenkel, I. (2018). Ludność wiejska. In: J. Wilkin i I. Nurzyńska (ed.). Polska wieś 2018. Raport o stanie wsi (p. 25-64). Warszawa: Wydawnictwo Scholar.

GUS (2014). Charakterystyka gospodarstw rolnych w 2013 roku. Warszawa: GUS.

GUS (2017). Charakterystyka gospodarstw rolnych w 2016 roku. Warszawa: GUS.

GUS (2015). Sytuacja gospodarstw domowych w 2014 w świetle wyników badania budżetów gospodarstw domowych. Warszawa: GUS.

GUS (2019). Sytuacja gospodarstw domowych w 2018 w świetle wyników badania budżetów gospodarstw domowych. Warszawa: GUS.

Halamska, M. (2016). Struktura społeczna ludności wiejskiej na początku XXI wieku. In: M. Halamska, S. Michalska, R. Śpiewak, Studia nad struktura społeczna wiejskiej Polski (p. 11-93). Vol. 1. Warszawa: IRWiR PAN.

Juchniewicz, M., Kambo, K., Michalak, P. (2018). Poziom i struktura dochodów rodzin rolników w gospodarstwach prowadzacych rachunkowość w $2016 r$. Warszawa: IERiGŻ-PIB.

Kinsella, J., Wilson, S., de Jong, F., Renting, H. (2000). Pluriactivity as a Livelihood Staregy in Irish farm Households and Its Role in Rural Development. Sociologia Ruralis, Vol. 40, No. 4, p. 481-496.

Kowalski, A. (ed.) (2015). Analiza produkcyjno-ekonomicznej sytuacji rolnictwa i gospodarki żywnościowej w 2014 roku. Warszawa: IERiGŻ-PIB.

Krzyworzeka, A. (2014). Rolnicze strategie pracy i przetrwania. Studium z antropologii ekonomicznej. Warszawa: Wydawnictwa Uniwersytetu Warszawskiego.

Other gainful activity: pluriactivity and farm diversification in EU-27 (2008). Brussels: European Comission, Directorate - General for Agriculture and Rural Development.

R-SGR. Badanie struktury gospodarstw rolnych (2013). Warszawa: GUS.

R-SGR. Badanie struktury gospodarstw rolnych (2016). Warszawa: GUS.

Strategia zrównoważonego rozwoju wsi, rolnictwa i rybactwa 2030 (2019). Warszawa: Ministerstwo Rolnictwa i Rozwoju Wsi.

Thomson, K.J. (2019). Rural Diversification and Job Creation in the EU. In: S. Davidova, K.J. Thomson, A. Mishra (ed.), Rural Policies and Employment: Transatlantic Experiences (p. 287-300). World Scientific Europe.

Van der Ploeg, J.D. (2009). The New Peasantries. Struggle for Autonomy and Sustainability in Era of Empire and Globalization. London - Sterling: EARTHSCAN. 


\title{
WIELOZAWODOWOŚĆ W RODZINACH ROLNICZYCH W POLSCE. STAN I ZMIANY W LATACH 2013-2016
}

\begin{abstract}
Abstrakt
Celem artykułu jest zaprezentowanie stanu $i$ zmian $w$ wielozawodowości rodzin rolniczych $w$ Polsce $w$ latach 2013-2016. Analiza oparta została o dane z reprezentacyjnego badania struktury gospodarstw rolnych (BSGR), do którego zobowiązany jest każdy kraj UE. Jej wyniki sa następujace: 1) w 2016 r. jedynie 1,3\% osób łączyło pracę rolniczą z pozarolnicza, podczas gdy w 2013 r. było to 31,5\%, 2) dywersyfikacje działalności innej niż rolnicza, ale bezpośrednio zwiazana z gospodarstwem rolnym prowadzi $w$ Polsce wciąz relatywnie niewielki odsetek gospodarstw: $w 2016 r-2,9 \%$; 3) ponad polowa gospodarstw domowych z uzytkownikiem gospodarstwa rolnego, oprócz dochodów z działalności rolniczej uzyskiwała dochody z pracy najemnej (wśród źródeł zarobkowych praca najemna byla najpopularniejsza forma pracy poza gospodarstwem rolnym, podobnie jak w latach 2005-2010). Najbardziej zaskakujaca zmiana dotyczyła zwiększenia o ponad pót miliona liczby osób pracujacych wyłacznie $w$ gospodarstwie rolnym, a zmniejszenia o ponad milion liczby osób wielozawodowych $i$ tym samym przerwania wieloletniej proporcji 1:3 osób wielozawodowych w stosunku do osób zajmujących się jedynie rolnictwem. Możliwe przyczyny takiego stanu rzeczy moga być nastepujace: spadek liczby gospodarstw, w tym gospodarstw do 1 ha, w których najwięcej jest osób wielozawodowych, powrót do specjalizacji, zjawisko repezantyzacji, ewentualny wptyw programu 500+ na odchodzenie od prac pozarolniczych i w końcu możliwość wystapienia błędu statystycznego w badaniach 2016 r. (inne badanie - BAEL nie wykazuje spadku znaczenia wielozawodowości). Sprawa jest o tyle ważna, że badanie SGR jest źródtem oficjalnych krajowych danych dla statystyki UE.
\end{abstract}

Słowa kluczowe: Polska, rodziny rolnicze, dywersyfikacja, wielozawodowość.

Accepted for print: 18.06 .2020$.

Unless stated otherwise all the materials on the website are available under the Creative Commons Attribution 4.0 International license.

Some rights reserved to the Institute of Agricultural and Food Economics - National Research Institute.

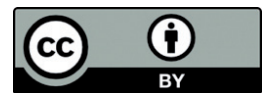

